سازگَارى هاى ساختارى ييجٌك ايرانى، گَونه در معرض خطر سواحل شمالى ايران

\author{
فائزه عاشقيان، صديقه كليج و ناصر جعفرى

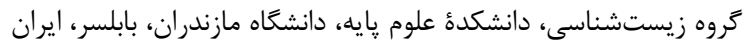 \\ مسئول مكاتبات: صديقه كليج، s.kelij@umz.ac.ir
}

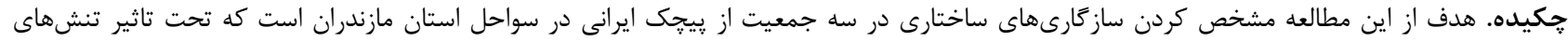

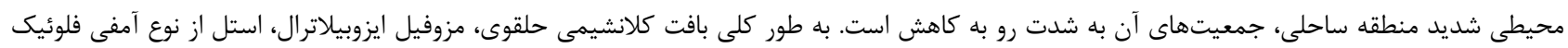

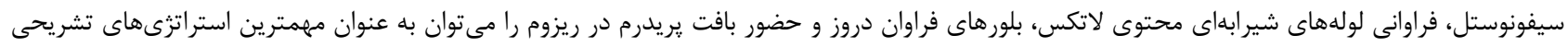

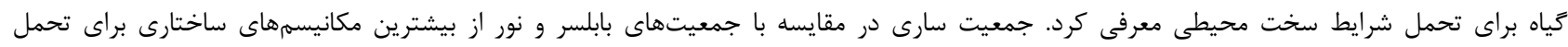

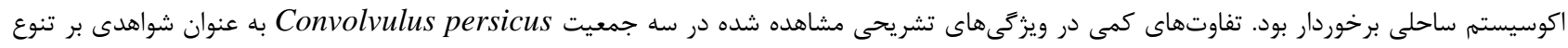

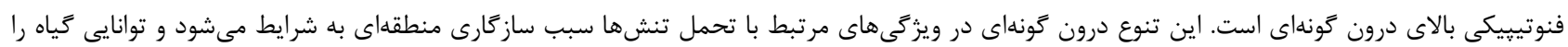
براى مقابله با تغييرات محيطى افزايش ميى دهند
\end{abstract} وازههاى كليدى. تشريح، بافت استحكامى، تنشهاى محيطى، سواحل ايرانى، ماسه رست

\title{
The structural adaptations of Convolvulus persicus, an endangered plant in the northern coasts of Iran
}

\author{
Faezeh Asheqian, Sedigheh Kelij \& Naser Jafari \\ Department of Biology, Faculty of Basic Sciences, University of Mazandaran, Babolsar, Iran \\ Correspondent author: Sedigheh Kelij, s.kelij@umz.ac.ir
}

\begin{abstract}
The purpose of this research was to identify the structural adaptations in three populations of Convolvulus persicus L. on coastal areas in Mazandaran Province, whose populations of which are severely reducing due to the intense environmental stresses of the coastal zone. In general, annular collenchyma, isobilateral mesophyll, amphiphloic siphonostele, abundant presence of laticiferous tubes, numerous druse crystals and the presence of periderm in rhizome can be introduced as the most important morpho-anatomical strategies utilized against harsh environmental conditions. Sari population was foud to have the most various structural toleration mechanisms in comparison with Babolsar and Nour populations. Few differences were observed in anatomical characteristics in the three populations of Convolvulus persicus as the evidence for high intra-specific phenotypic variability, leading to local adaptation and increase of the tolerability of plants against environmental changes.
\end{abstract}

Keywords. anatomy, Caspian coasts, environmental stresses, mechanical supporting tissue, psammophyte 
مازندران به منظور شناخت و ارزيابى ويزگى هاى ساختارى دخيل

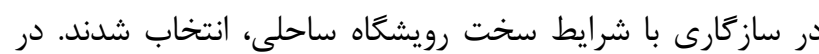

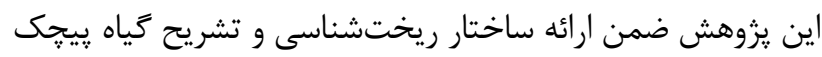

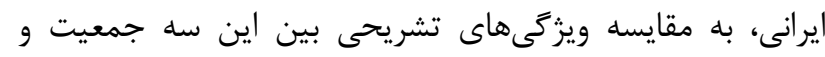

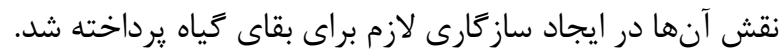

\section{مواد و روشها}

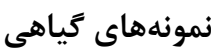

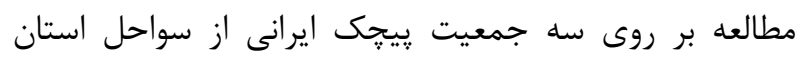

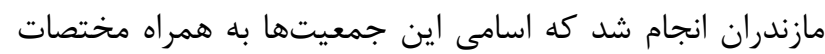

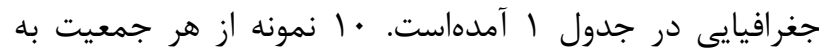
طور تصادفى به منظور مطالعات ساختارى انتخاب شدند. مطالعات تشريحى

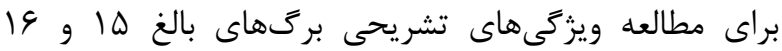
ميانكَرهاى بالغ هفتم و · التانتىمتر ابتدايى ريزوم (از محل

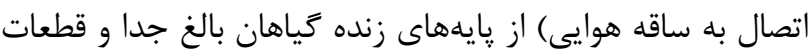

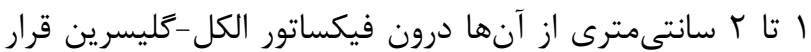

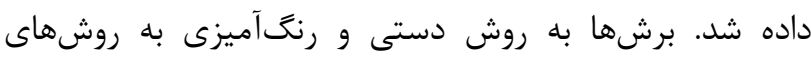

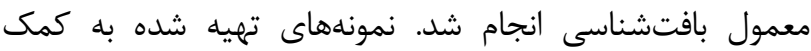

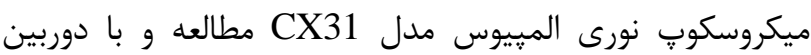
Canon

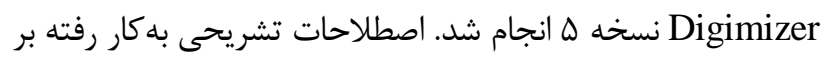
مبناى كتاب "Plant Anatomy Esau" است (Evert, 2006).

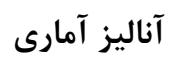

IV ويزگى تشريحى حداقل در • ا نمونه از هر جمعيت مطالعه

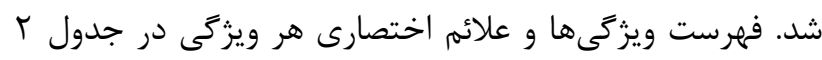

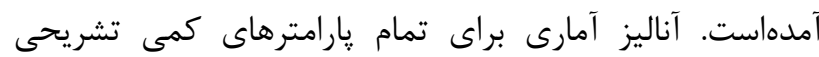

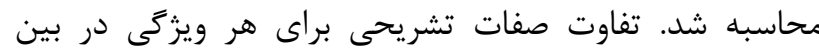

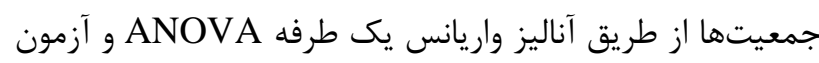
Posthoc

$$
\text { برتنايج }
$$

برگَها به رنغَ سبز كم رنغ تا نقرهاى، يوشيده از كركهاى

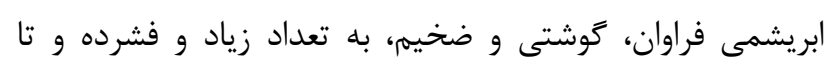
حدى در مناطق فوقانى ساقه هميوش و با دمبركى كوتاه و مسطح و شياردار هستند. شكل بيهنك بيضوى تا تخمم مرغى بـ با رأس كن كند و در سطح تحتانى گرد يا كوهاى، حاشيه صاف و رَّبندى آن از باز
مقلدمه

كياه يِيجى ايرانى . Convolvulus persicus L متعلق به تيره

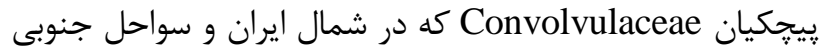
درياى خزر كسترش دارد، از جمله گونههاى با ارزش ماسهرست و هالوفيت است (Akhani et al., 2010). طبق گَزارشات متعدد از آن به عنوان يك كياه در معرض خطر در ايران و ساير كشورها نام برده مىشود ( Safavi, 2016; Fagaras \& Jianu, 2016; Strat

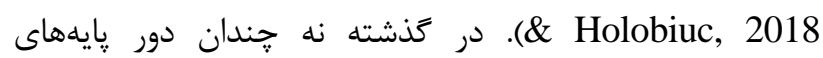
متعددى از آن از شرق تا غرب سواحل درياى خزر مشاهده مىشد اما امروزه عرصه رويشى اين كياه به شدت محدود شده است و جمعيتهاى آن به طور مؤثرى به دليل توسعه شهرها و روستاها،

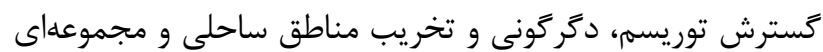
از اين عوامل كاهش يافته است (Safavi et al., 2016). در كشور رومانى بررسىهايى جهت حفاظت در شيشه اين گياه ارزشمند

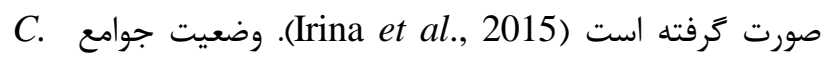
persicus

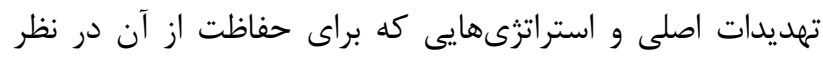
كرفته شده بود مورد ارزيابى قرار كرفته است ( Strat \&

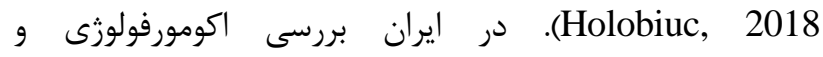
اكوفيزيولوزى C.persicus به عنوان يك گياه ماسهرست ساحلى

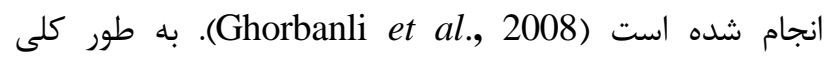

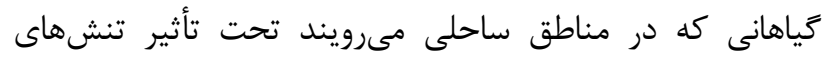
مختلفى جون شورى بالاى خاك، دماى بالا، بادهاى شديد، اسيرى

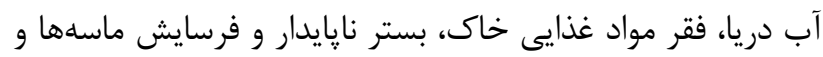

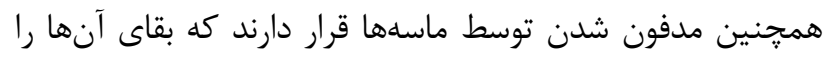
تهديد مى كند (Fenu et al., 2012). معمولا اين دسته از كياهان داراى سازوكارهايى براى سازكارى با اين شرايط سخت محيطى

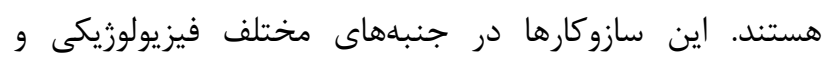

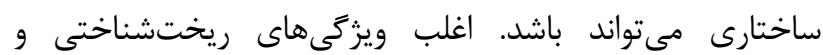
تشريحى به خصوص از نظر كمى به شدت تحت تأثير عوامل بوم

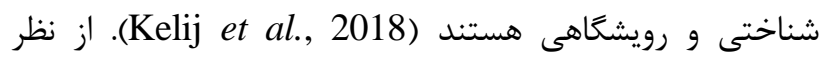

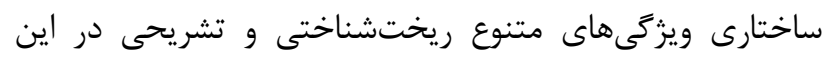

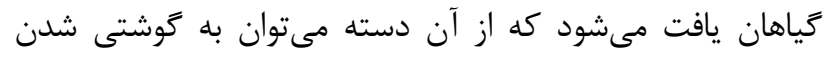

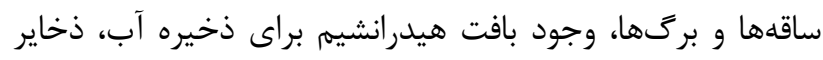

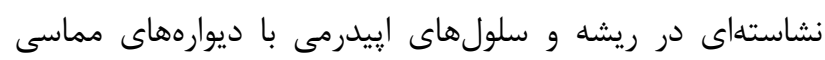
خارجى، كوتيكول ضخيم و جوبى شدن سلولهاى يوست ريشه

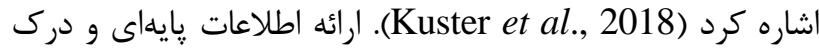

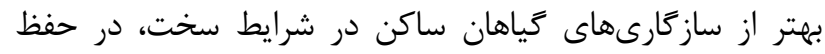

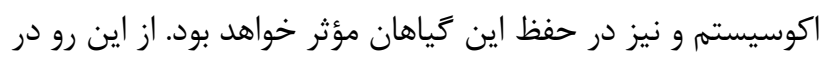

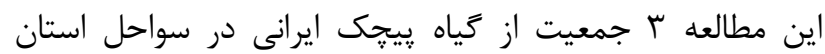




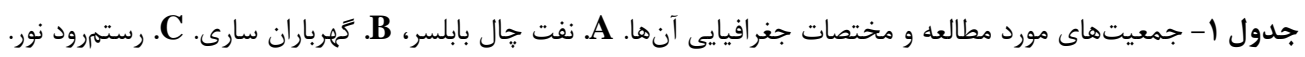

Table 1. The studied populations and their geographical coordinates. A. Naft Chal Babolsar. B. Gohar Baran Sari. C. Rostam Rood Nour.

\begin{tabular}{|c|c|c|c|}
\hline 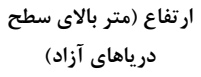 & طول و عرض جغرافيايى & مكان نمونه بردارى & مايت \\
\hline-28 & $\begin{array}{l}\text { N36 } 6^{\circ} 44.0311^{\prime} \\
\text { E}^{\circ} 2^{\circ} 47.6602^{\prime}\end{array}$ & نفت حال بابلسر & A \\
\hline-20 & $\begin{array}{l}\mathrm{N} 36^{\circ} 50.054^{\prime} \\
\mathrm{E}^{\prime} 3^{\circ} 12.9681^{\prime}\end{array}$ & كمرباران سارى & B \\
\hline-11 & $\begin{array}{r}\text { N36 } 35.5149^{\prime} \\
\text { E52 } 5.2984^{\prime}\end{array}$ & رستمرود نور & $\mathrm{C}$ \\
\hline
\end{tabular}

جدول r - ويزگى هاى تشريحى به همراه علائم اختصارى آنها.

Table 2. Anatomical characters and their abbreviated forms.

\begin{tabular}{|c|c|c|c|}
\hline علامت اختصارى & Anatomical Characteristic & صفت تشريحى & اندام \\
\hline Lbth & Leaf Blade Thickness & ضخامت يهنك برى & \multirow{7}{*}{ برى } \\
\hline Lmth & Leaf Midrib Thickness & ضخامت ركبرى ميانى & \\
\hline Lmsa & Leaf Midrib Stele Area & مساحت استل رَّبرَّ ميانى & \\
\hline Lucoth & Leaf Upper Collenchyma Thickness & ضخامت كلانشيم فوقانى & \\
\hline Llcoth & Leaf Lower Collenchyma Thickness & ضخامت كلانشيم تحتانى & \\
\hline Llan & Leaf Laticiferous tubes Number & تعداد لولههاى شيرابهاى & \\
\hline Lcrn & Leaf Crystals Number & ت ت تعداد بلورها & \\
\hline Scsa & Stem Cross Section Area & سطح مقطع عرضى & \multirow{5}{*}{ ساقه } \\
\hline Scth & Stem Cortex Thickness & ضخامت يوست & \\
\hline Svth & Stem Vascular Tissue Thickness & ضخامت بافت آوندى & \\
\hline Sxth & Stem Xylem Thickness & ضخامت بافت هوب & \\
\hline Scoth & Stem Collenchyma Thickness & ضخامت بافت كلانشيمى & \\
\hline Rcsa & Rhizome Cross Section Area & سطح مقطع عرضى & \multirow{5}{*}{ 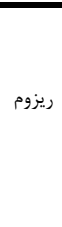 } \\
\hline Rcth & Rhizome Cortex Thickness & ضخامت يوست & \\
\hline Rxth & Rhizome Xylem Thickness & ضخامت بافت حوب & \\
\hline Rphth & Rhizome Phloem Thickness & ضخامت بافت آبكش & \\
\hline Rmed & Rhizome Metaxylem Diameter & قطر عناصر متاكز يلمى & \\
\hline
\end{tabular}

يارانشيه نردبانى در هر دوسطح برگ به صورت ب لايهاى ديده

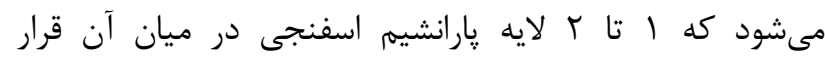
مى گيرد. در محل رگبرى ميانى در زير إيدرم در هر دو سطح فوقانى و تحتانى كلانشيم حلقوى قابل تشخيص است كه ضخامت كلانشيم در سطح تحتانى برى نسبت به فوقانى بيشتر است و همجنين بيشترين ضخامت كلانشيم در هر دو سطح فوقانى و

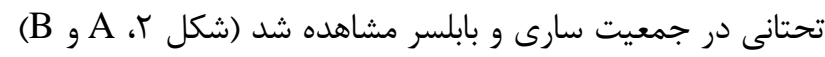

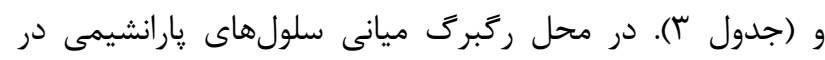

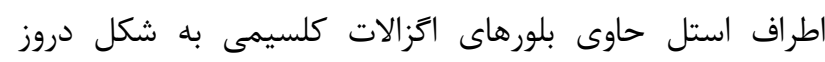

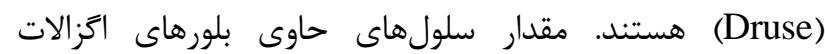
كلسيمى در جمعيت سارى و بابلسر بالاتر و در جمعيت نور به طور قابل ملاحظهاى كمتر بود (جدول ؟). همجنين در بين سلولهاى
نوع شانهاى است. برگها در وضعيت مايل قرار مى گيرند و تعدادى از آنها حالت رل مانند داشته كه برخى از سمت فوقانى به سمت

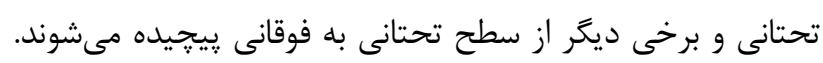
برگهاى قاعدهاى در تماس مستقيم با خاى ديده مىشوند (شكل و A 1

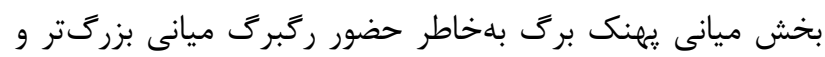

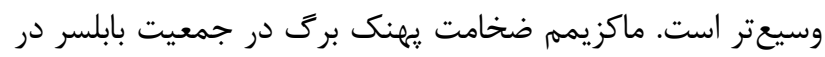
حالى كه ماكزيمم ضخامت ركبرى ميانى در جمعيت سارى مشاهده شد. برى ساختار دورويه متقارن يا ايزوبيلاترال را نشان مى دهد كه در هر دو سطح فوقانى و تحتانى برى إييدرم تك لايه

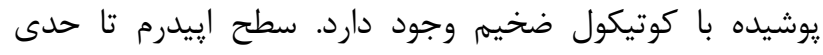
موجدار و در هر دو سطح برى داراى كركهاى طويل است. 
گزيلمى به جمعيت سارى تعلق داشت. مغز ساقه به نسبت وسيع، يارانشيمى است و همجنين با لولههاى شيرابهاى و بلورهاى دروز

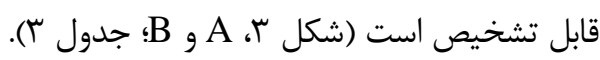

ريزوم

ريزومها بسيار طويل و باريك حاوى ريشههاى نابجاى كوتاه فراوان و نيز به تعداد كم، گرهها و ميان گرههاى كوتاه زياد و جوانهای نابجا هستند (شكل I، C). سطح مقطع عرضى ريزوم بصورت مدور و تا حدى موجدار ديده مىشود كه ماكزيمم وسعت

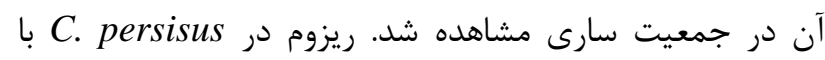
ساختار يسين مشاهده مىشود كه سطح خارجى آن را بافت محافظ يريدرم تشكيل مى دهد كه خود شامل بافت فلم با r تا س لايه سلولهاى جوبينبهاى در سطح خارجى، لايه فلوزن در ميان و بافت فلودرم حاوى سلولهاى پارانشيمى گِيسين است.

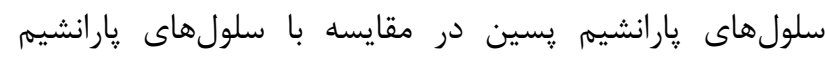
نخستين كه در سطح داخلى آنها قرار مى گيرند از نظر اندازه كوجكتر و فشردهتر به نظر مىرسند و در كل يارانشيم پسين از وسعت كمترى برخوردار است. تجمع سلولهاى حاوى بلورهاى

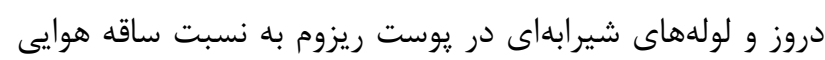

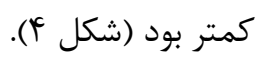

به طور كلى در جمعيت سارى ضخامت يوست ريزوم متناسب با سطح مقطع عرضى آن از بالاترين مقدار برخوردار بود. در ريزوم نيز

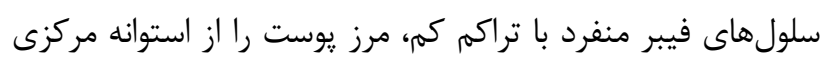
جدا مى كند. بافت آبكش نخستين و يسين منطبق بر هم به صورت حلقهاى كامل و همجنين منطبق بر هوب قابل مشاهده است. جوب

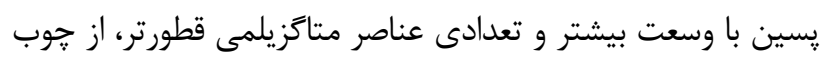
نخستين كه در سطح درونى آن واقع شده است متمايز مىشود. ضخامت بافت جوب ريزوم در جمعيت نور از بالاترين مقدار برخوردار

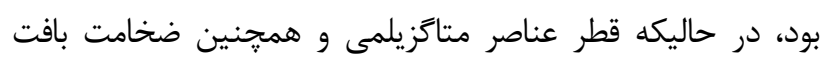
آبكش در بين سه جمعيت از تفاوت معنى دارى برخوردار نبود. در

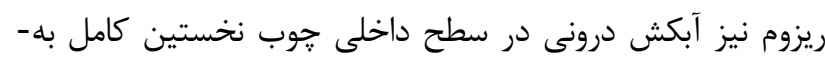

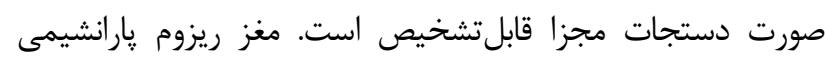
است و تا حدودى حفرهدار ديده مىشود (شكل أ؛ جدول س).

بحث

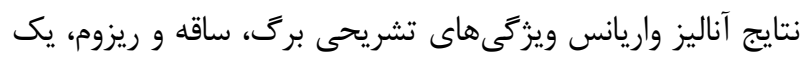

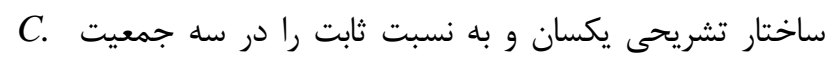
persicus
يارانشيمى در اين مكان لولههاى شيرابهاى حاوى ذرات كروى لاتكس قابل تشخيص است كه توسط أل، ه تا \& سلول مسطح احاطه مىشود. كمترين تعداد لولههاى شيرابهاى در جمعيت نور مشاهده شد. استل در محل رگبرگ ميانى از نوع يروتوستل است

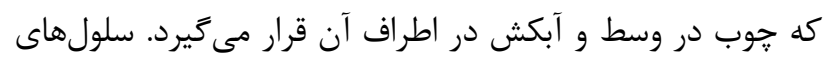
يارانشيمى آبدار با ديوارههاى نازك نيز در اطراف استل قابل مشاهده است. مساحت استل رگبرى ميانى در جمعيت سارى از

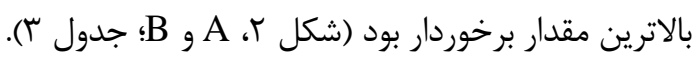

ساقه

ساقه هوايى بدون انشعاب و يا با انشعابات كم تا متوسط به

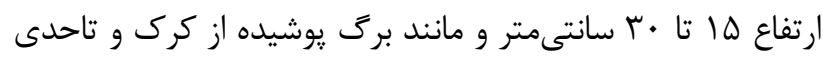
گوشتى است. ساقه راست و مستقيهم نيست بلكه تاحدى انحنا دار

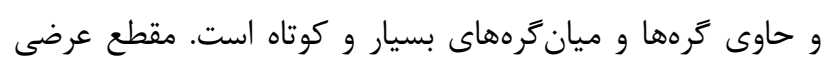
ساقه به صورت گرد قابل مشاهده است (شكل ا، B B). جمعيت نور بالاترين مساحت مقطع عرضى ساقه و جمعيت سارى كمترين آن را نشان دادند. ساختار كلى ساقه را در تمام جمعيتها مى تونوان اينگونه تشريح كرد كه سطح خارجى آن يوشيده از كركهاى

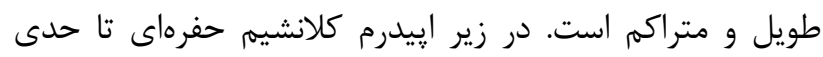

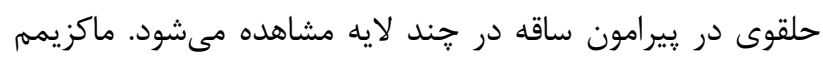

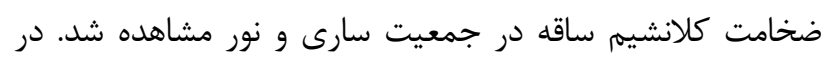
سطح داخلى كلانشيم سلولهاى يارانشيمى يوست ساقه حضور

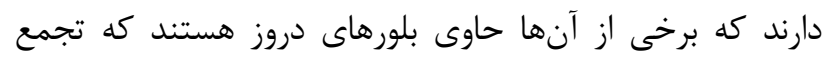
بلورها در ساقه جمعيت بابلسر بيشتر است. در بين سلولهاى باى بلون

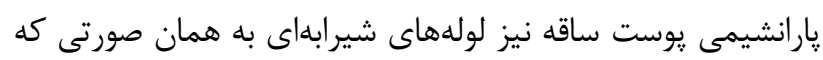

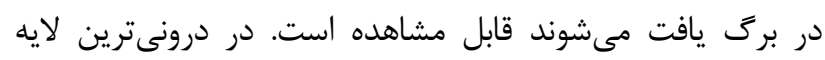
يوست عناصر اسكلرانشمى از نوع فيبر به صورت منفرد و با تراكم كم مشاهده مىشوند كه به نوعى مشخص كننده مرز بين :يوست و

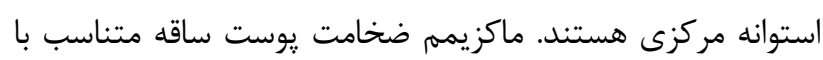

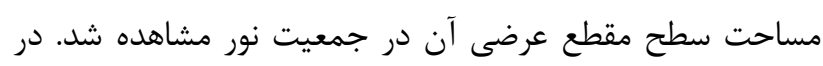

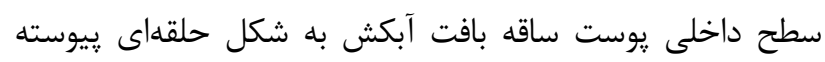

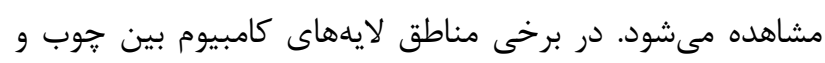
آبكش قابل تشخيص است. در سطح داخلى كامبيوم بافت جوب تئى حضور دارد كه بخش يسين و نخستين آن قابل تشخيص است. در ساقه C. persicus حالت آمفىفلوئيك سيفونوستل مشاهده مىشود كه آبكش علاوه بر سطح خارجى در سطح داخلى جوب

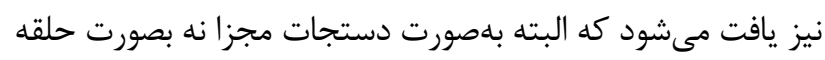
كامل است. ضخامت بافت آوندى در بين سه جمعيت از تفاوت معنى دارى برخوردار نبود اما ضخامت بافت جوب در جمئ لمعيت نور

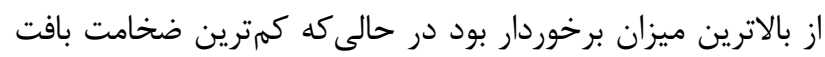




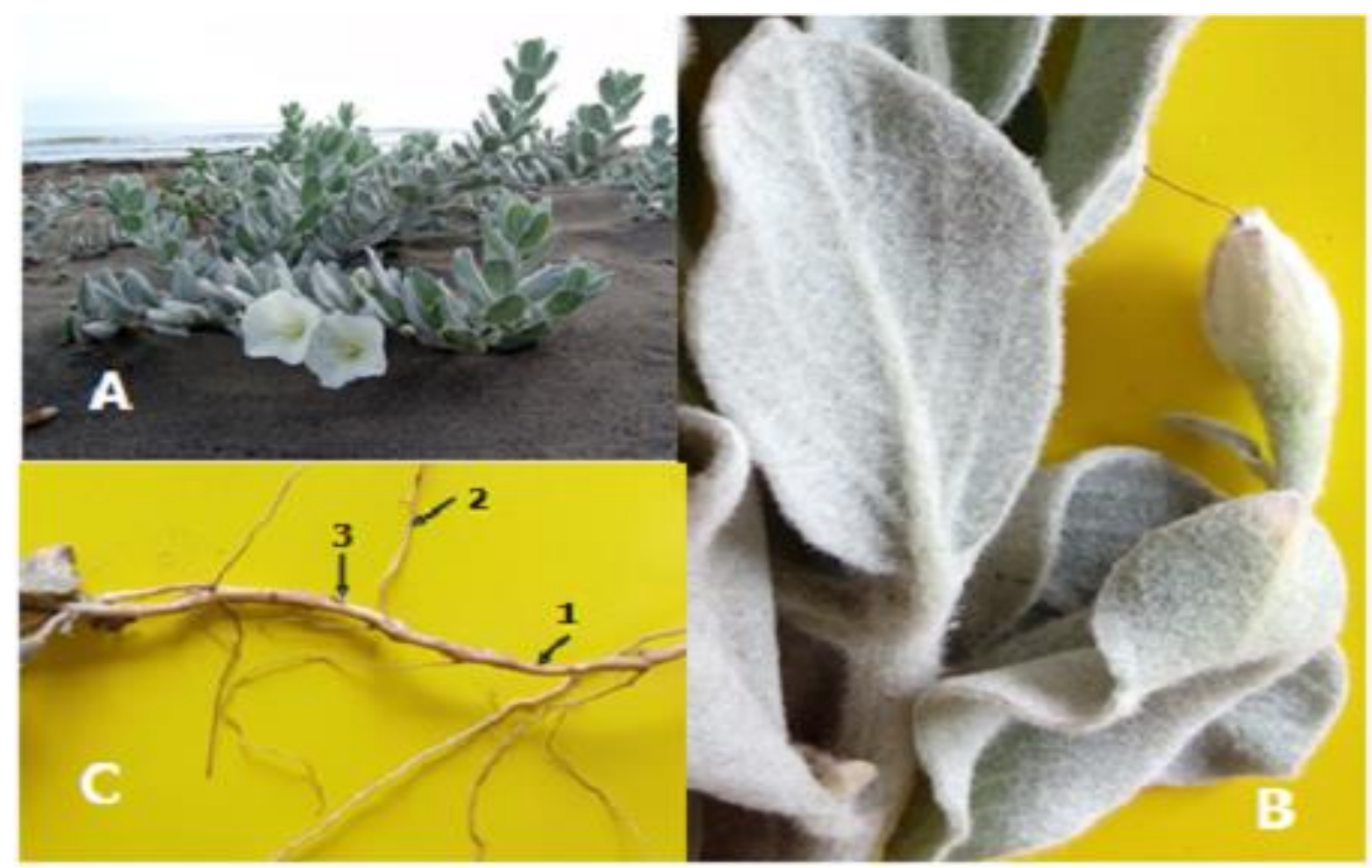

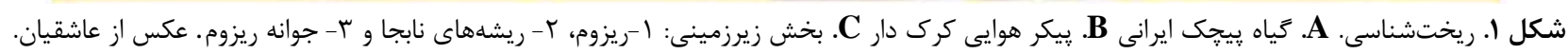

Fig. 1. Morphology. A. Convolvulus persicus. B. Hairy aerial body C. Underground area: 1-Rhizome, 2-Adventitus root and 3- Rhizome bud. Photo by Asheqian.

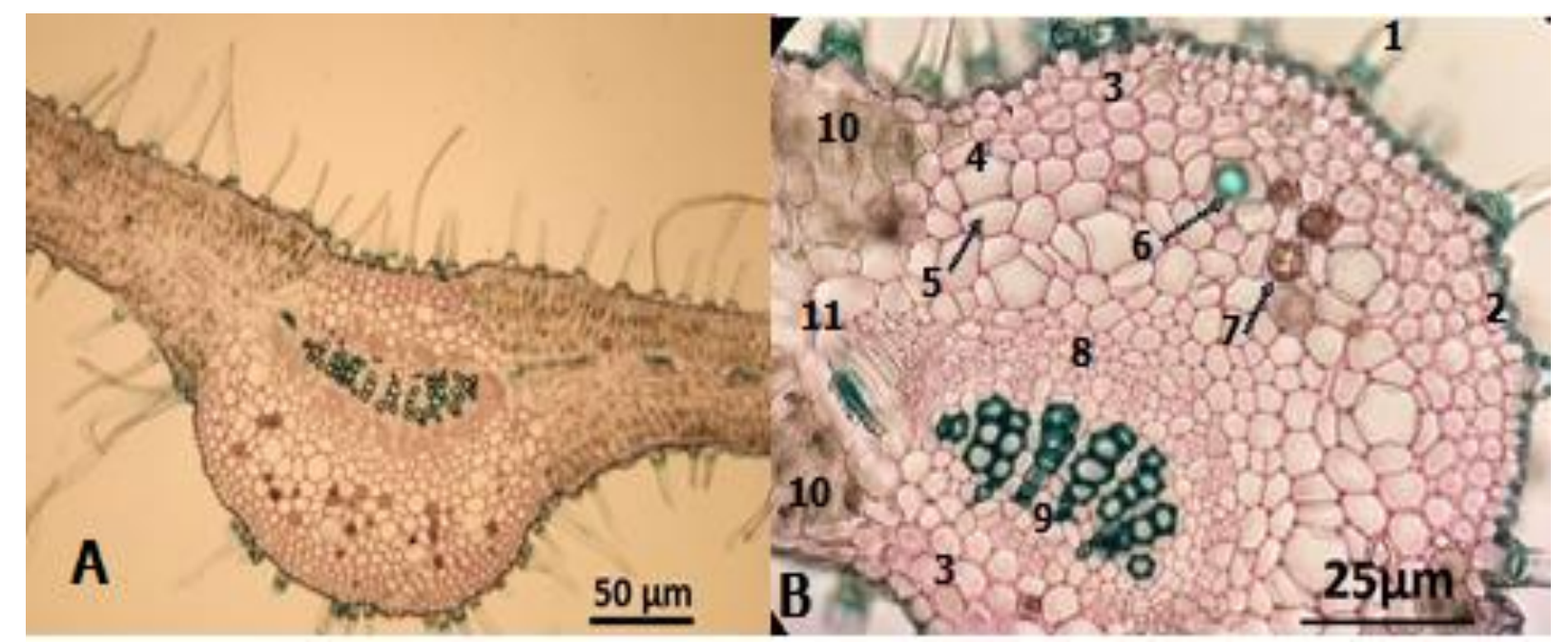

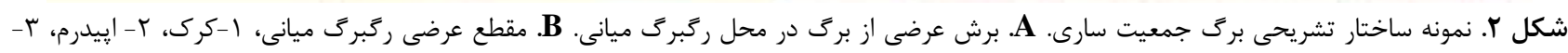

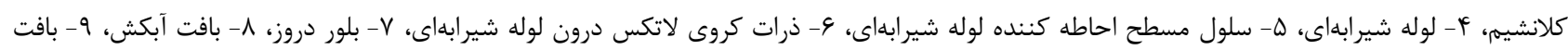

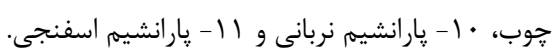

Fig. 2. Leaf anatomical structure. A. Leaf midrib cross section. B. Midrib cross section, 1- Trichome, 2- Epidermis, 3Collenchyma, 4- Laticiferous tubes, 5- Flat cells surrounding laticiferous tube, 6- Spherical latex particles in laticiferous tube, 7- Druse crystal, 8- Phloem, 9- Xylem, 10- Palisade parenchyma, 11- Spongy parenchyma. 

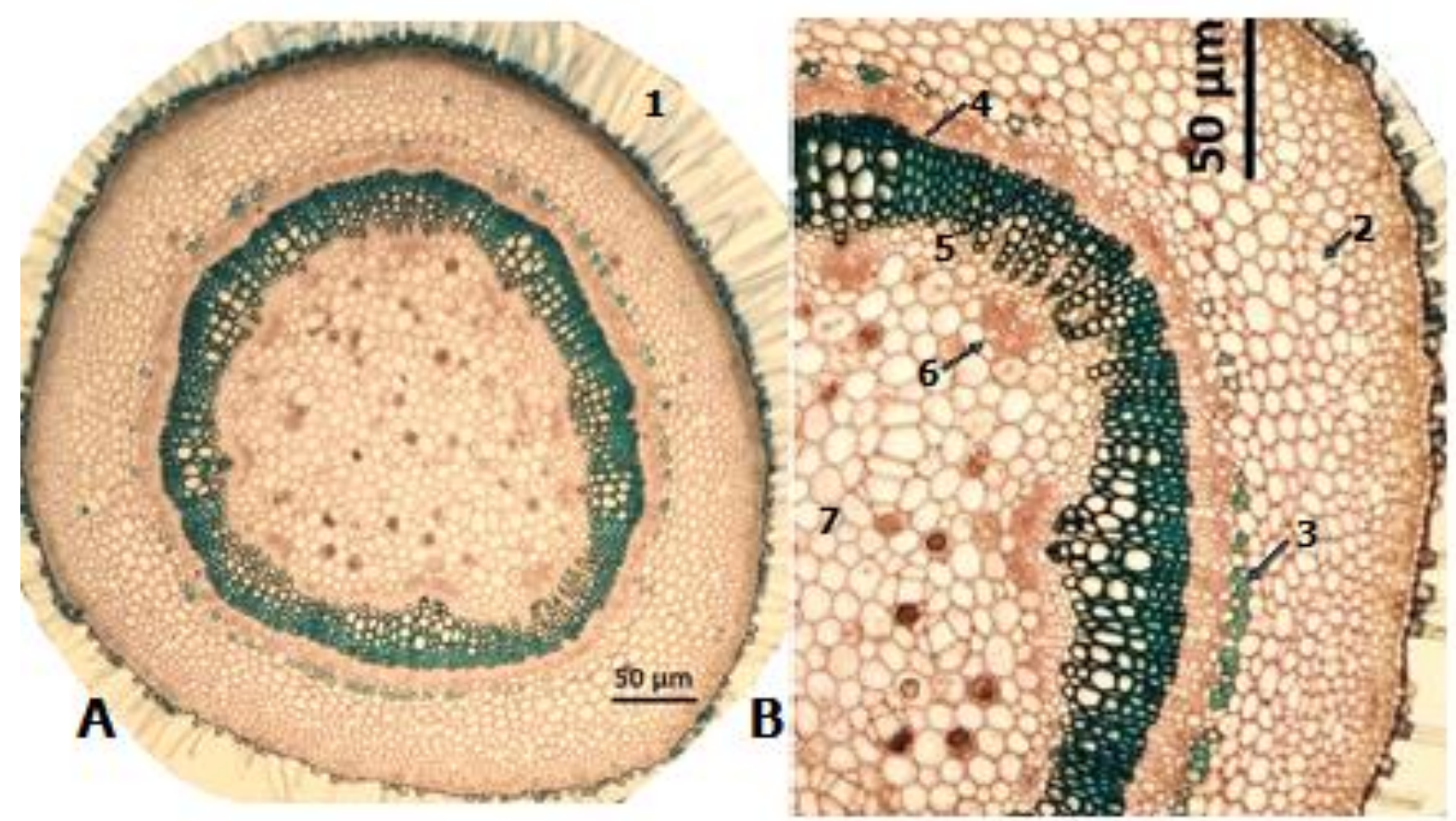

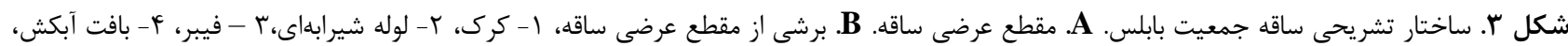

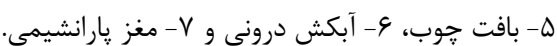

Fig. 3. Stem anatomical structure. A. Stem cross section. B. Cut of stem cross section 1- Trichome, 2- Laticiferous tube, 3- Fiber, 4- Phloem, 5- Xylem, 6- Inner phloem 7- Parenchymatic pit.

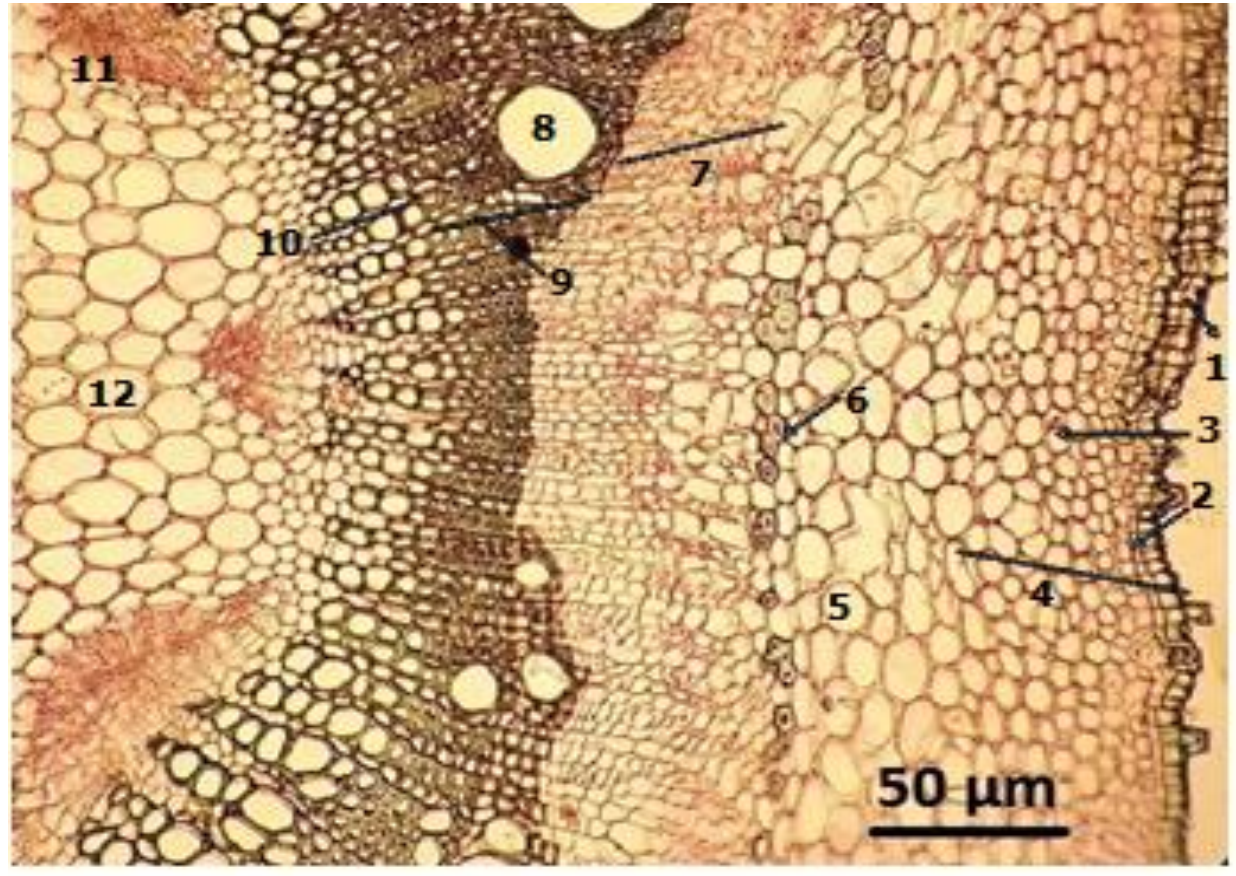

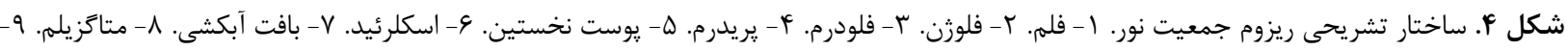

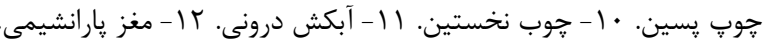

Fig. 4. Rhizome anatomical structure. 1- Phellem, 2- Phellogen, 3- Phelloderm, 4- Priderm, 5- Cortex, 6- Sclereid, 7Phloem, 8- Metaxylem, 9- Secondary xylem, 10- Primary xylem, 11- Inner phloem, 12-Paranchymatic pit. 
جدول بـ - نتايج آناليز Post hoc و ANOVA دادهاى تشريحى C. persicus بين سه جمعيت بابلسر، سارى و نور.

Table 3. One-way ANOVA and Post hoc analysis of anatomical characters of three populations C. persicus Babolsar, Sari and Noor.

\begin{tabular}{|c|c|c|c|c|c|}
\hline Anatomy Traits & $\begin{array}{l}\text { Babolsar } \\
\text { Mean } \pm \text { St. E }\end{array}$ & $\begin{array}{l}\text { Sari } \\
\text { Mean } \pm \text { St. E }\end{array}$ & $\begin{array}{l}\text { Nour } \\
\text { Mean } \pm \text { St. E }\end{array}$ & $\mathrm{F}$ & Sig \\
\hline Lbth & $3.03 \pm 0.1^{\mathrm{a}}$ & $2.62 \pm 0.08^{b}$ & $2.43 \pm 0.06^{b}$ & 12.16 & 0.000 \\
\hline Lmth & $5.50 \pm 0.2^{b}$ & $6.37 \pm 0.1^{\mathrm{a}}$ & $5.26 \pm 0.1^{b}$ & 8.56 & 0.002 \\
\hline Lmsa & $5.35 \pm 0.7^{\mathrm{ab}}$ & $6.71 \pm 0.5^{\mathrm{a}}$ & $4.60 \pm 0.4^{b}$ & 3.44 & 0.05 \\
\hline Lucoth & $0.44 \pm 0.0^{\mathrm{a}}$ & $0.51 \pm 0.0^{\mathrm{a}}$ & $0.34 \pm 0.0^{\mathrm{b}}$ & 10.33 & 0.001 \\
\hline Llcoth & $0.60 \pm 0.0^{\mathrm{a}}$ & $0.62 \pm 0.0^{\mathrm{a}}$ & $0.47 \pm 0.0^{\mathrm{b}}$ & 5.83 & 0.010 \\
\hline Llan & $7 \pm 0.3^{a}$ & $7 \pm 0.3^{a}$ & $5.71 \pm 0.2^{b}$ & 5.17 & 0.017 \\
\hline Len & $8.71 \pm 1.1^{\mathrm{a}}$ & $9.71 \pm 0.5^{\mathrm{a}}$ & $4.14 \pm 0.8^{b}$ & 10.93 & 0.001 \\
\hline Scsa & $410 \pm 11.5^{\mathrm{ab}}$ & $357 \pm 12.9^{b}$ & $445 \pm 31.75^{\mathrm{a}}$ & 4.40 & 0.020 \\
\hline Scth & $2.87 \pm 0.0^{\mathrm{c}}$ & $3.06 \pm 0.0^{\mathrm{b}}$ & $3.31 \pm 0.0^{\mathrm{a}}$ & 12.09 & 0.000 \\
\hline Svth & $3.38 \pm 0.0^{\mathrm{a}}$ & $2.60 \pm 0.0^{b}$ & $3.47 \pm 0.0^{\mathrm{a}}$ & 60.30 & 0.000 \\
\hline Sxth & $1.98 \pm 0.0^{\mathrm{b}}$ & $1.43 \pm 0.0^{\mathrm{c}}$ & $2.20 \pm 0.0^{\mathrm{a}}$ & 57.09 & 0.000 \\
\hline Scoth & $0.55 \pm 0.0^{\mathrm{b}}$ & $0.75 \pm 0.0^{\mathrm{a}}$ & $0.73 \pm 0.0^{\mathrm{a}}$ & 40.27 & 0.000 \\
\hline Rcsa & $250 \pm 9.8^{b}$ & $351 \pm 9.2^{\mathrm{a}}$ & $268 \pm 9.0^{b}$ & 32.88 & 0.000 \\
\hline Rcth & $2.33 \pm 0.1^{b}$ & $2.9 \pm 0.1^{\mathrm{a}}$ & $1.9 \pm 0.1^{\mathrm{c}}$ & 15.78 & 0.000 \\
\hline Rxth & $2.52 \pm 0.0^{b}$ & $2.72 \pm 0.1^{b}$ & $3.66 \pm 0.1^{\mathrm{a}}$ & 16.19 & 0.000 \\
\hline Rphth & $1.65 \pm 0.0^{\mathrm{a}}$ & $1.66 \pm 0.0^{\mathrm{a}}$ & $1.86 \pm 0.1^{\mathrm{a}}$ & 1.58 & 0.226 \\
\hline Rmed & $0.63 \pm 0.0^{\mathrm{a}}$ & $0.67 \pm 0.0^{\mathrm{a}}$ & $0.74 \pm 0.0^{\mathrm{a}}$ & 1.53 & 0.240 \\
\hline
\end{tabular}

دو رويه متقارن برى يعنى حضور پارانشيم نردبانى در هر دو

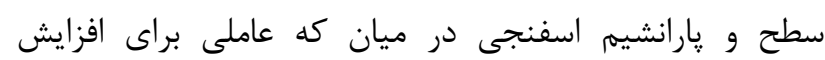
ضخامت يهنك است در زياهانى كه در نور بالا رشد مى كنند

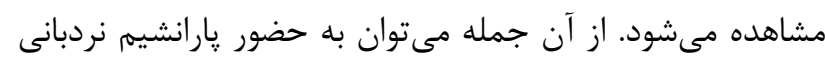

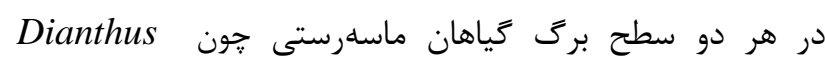
Pancratium و (Daniela et al., 2009) maritimus L. (Perrone et al., 2015) maritimum L. بيشترين ضخامت يهنك در جمعيت بابلسر مشاهده شد در حالى كه ضخامت رگبرگ ميانى در جمعيت سارى از بالاترين مقدار برخوردار بود كه اين افزايش ضخامت ركبرى ميانى ناشى ركى از افزايش ضخامت كلانشيم فوقانى و تحتانى ركبرى ميانى و همجنين افزايش مساحت استل ركبرى ميانى در جمعيت سارى است بيانگر سازكارى خوبى براى اين جمعيت است جرا كه حضور كلانشيم آن هم از نوع حلقوى كه بيشترين ضخامت ديواره در آن اتفاق افتاده است نشان دهنده نوعى سازعارى در ان
تشريحى از نظر اندازه و تعداد وجود دارد. به عبارت ديخر،

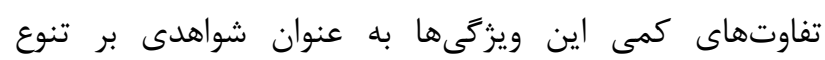

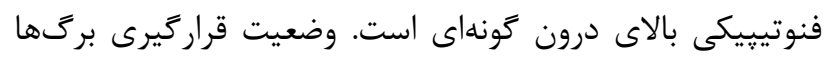
به طور مايل و همجنين تا حدى هميوشانى و فشرده بودن آنها

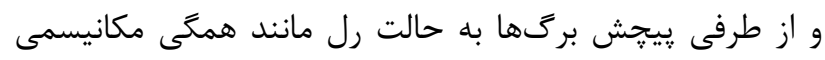

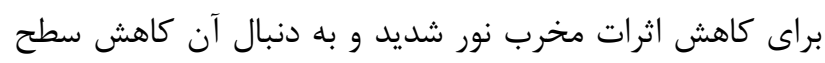
تبخير آب است. به طور كلى آرايش بركى و زاويه بركى نوعى

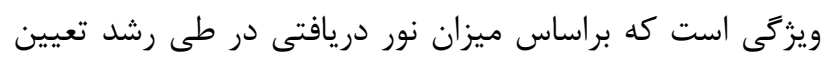

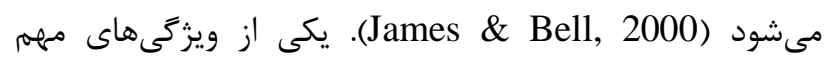
ريختى -تشريحى برى در زياهان ززروفيت، هالوفيت و به طور

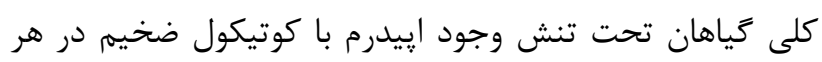
دو سطح يشتى و شكمى برى است كه اين سازگارى در برگهاى C. persicuc نيز مشاهده شد اين ويزگى كه به طور آشكار از دفع آب جلوگيرى مى كند و به دليل حضور موم در سطح كوتيكول نيز از تابش شديد نيز محافظت مى كند. ساختار 
كياهى، واكوئل •V Vا • N درصد وزن سلول را اشغال مى كند اين در حالى است كه در اين سلولها كه در ذخيره آب نقش دارنا دارند

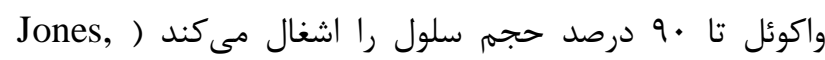

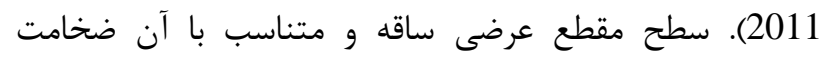
يوست ساقه در جمعيت نور از بالاترين مقدار برخوردار بود، در

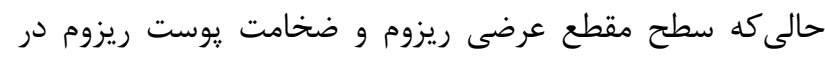

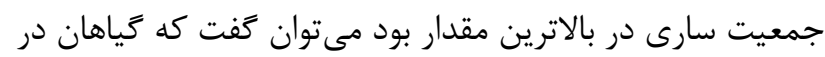
شرايط مختلف استراتزىهاى متفاوتى را در برابر شرايط نامساعد

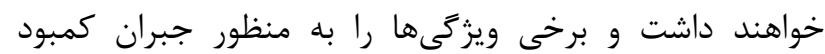
ويزگ هاى ديكر كسب مي كنند. درونى ترين لايه يوست در ساقه و ريزوم با عناصر اسكلرانشيمى

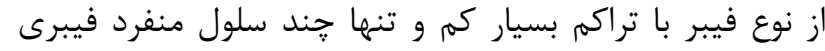

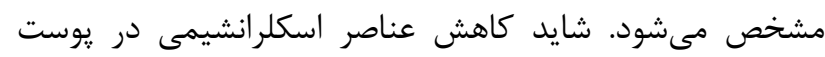
ساقه و ريزوم در C. persicus نوعى ضعف ساختارى به حساب آيد جرا كه يكى از متداولترين ياسخهاى تشريحى كياهان تحت تنشهاى مختلف زيستى و غيرزيستى تشكيل و توسعه بيشتر

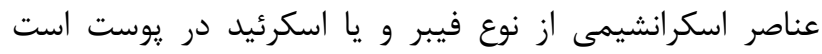
(Moura et al., 2010). وجود حالت آمفىفلوئيك سينفونوستل

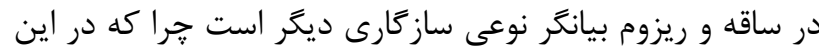

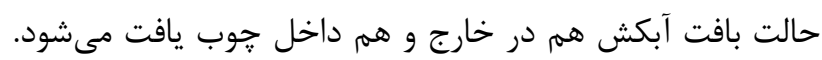
توسعه بافت آبكش براى گياهان تحت تنشهاى خشكى خدى و شورى

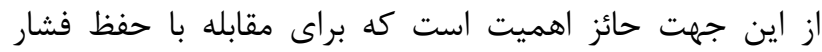

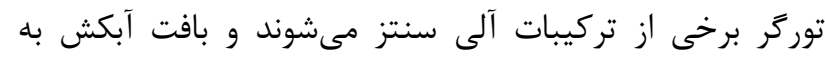
منظور انتقال اين نوع تركيبات توسعه مىيابد (Kelij, 2013).

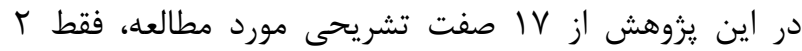

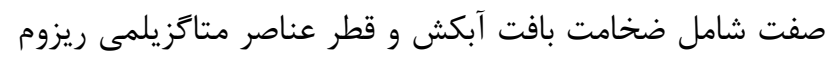

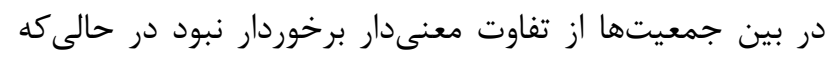
ها صفت ديكر در جداسازى جمعيتها مؤثر بودند. جمعيت C. persicus

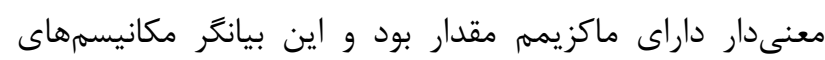

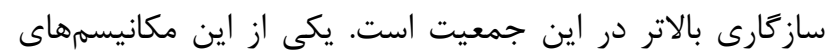

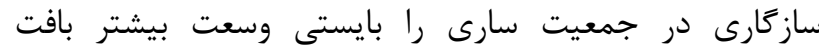

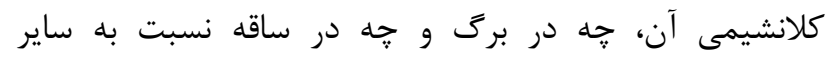

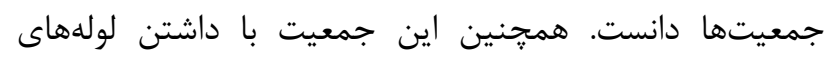

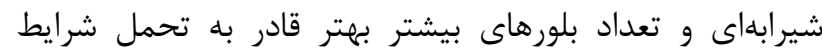

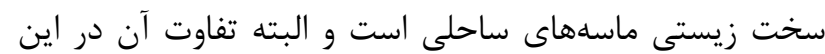

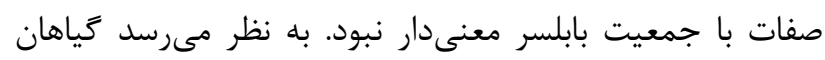
جمعيت نور با داشتن بافت جوب وسيعتر در ساقه و ريزوم

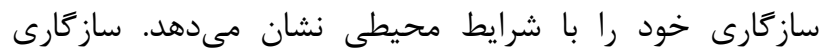

برابر وزش باد است كه اكوسيستمهاى ساحلى را تحت تاثير قرار

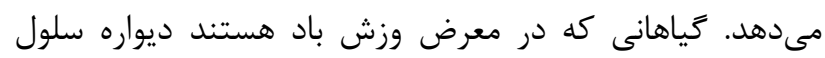

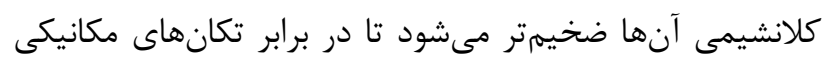
استحكام بيشترى داشته باشند (Leroux, 2012). مساحت استل بيشتر بيانكر افزايش تعداد عناصر آوندى در باشند جمعيت

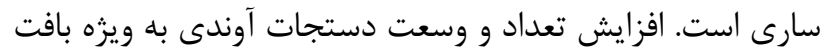

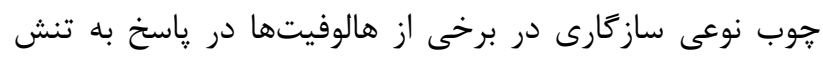

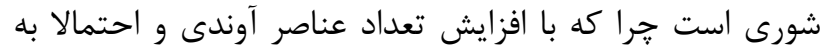

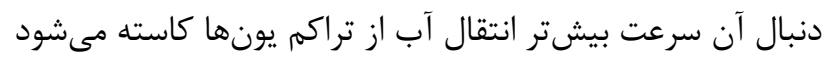

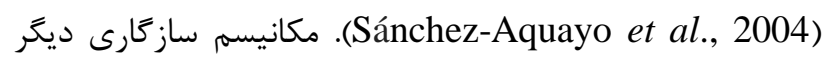
كه تمام اندامهاى مورد مطالعه C. persicus مشاهده شد حضور سلولهاى يارانشيمى محتوى بلورهاى اخزالاتكلسيمى به شكل

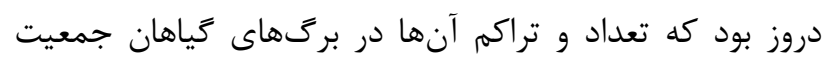
سارى از بالاترين مقدار برخوردار بود. تشكيل بلورها يك يُاسيخ

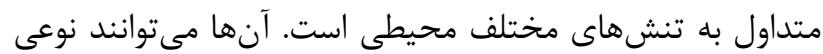

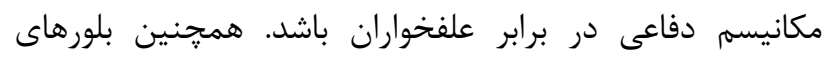

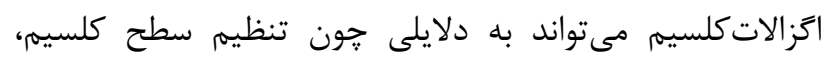

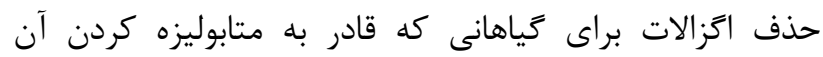

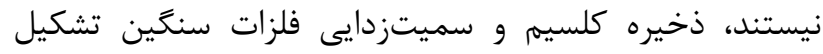
شوند. اما نقش مههم ديكر آنها در برقرار استحكام مكانيكى كياه از طريق افزايش وزن آن است. افزايش وزن بافتها در اندر اثر تشكيل

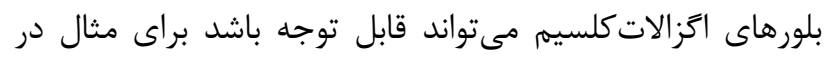

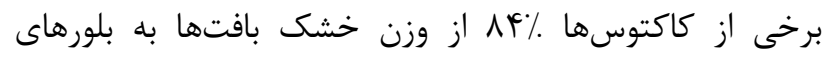

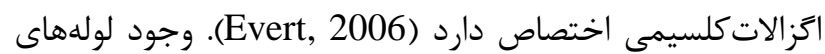

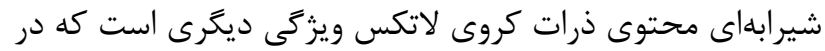

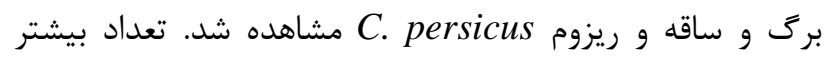
لولههاى شيرابهاى برى در در جمعيتهاى سارى و بابلسر مشاهده

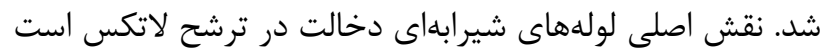

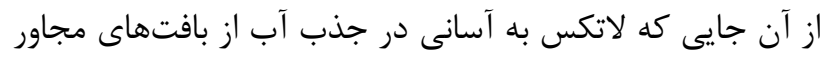

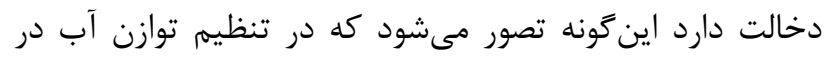

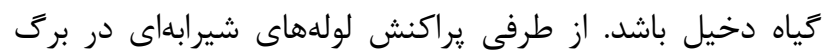
مىتواند نقش مكانيكى را براى اين ساختارهاى ترشحى يِيشنهاد

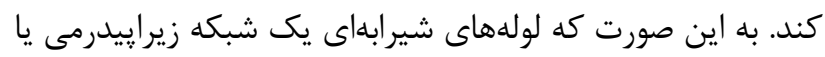

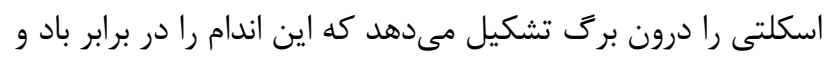

فرسايش ماسهاى حمايت مى كند (Daniela et al., 2009).

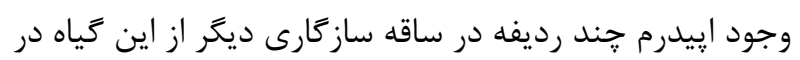

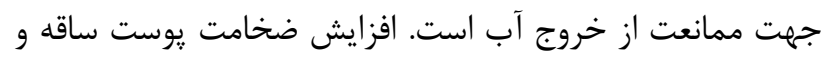
ريزوم ناشى از افزايش سلولهاى يارانشيمى است كه به به دليل

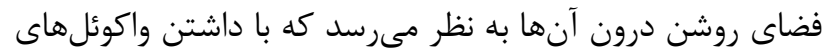

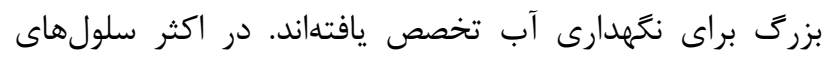




\section{REFERENCES}

Akhani, H., Djamali, M., Ghorbanalizadeh, A. and Ramezani, E. 2010. Plant biodiversity of Hyrcanian relict forests, $\mathrm{N}$ Iran: an overview of the flora, vegetation, palaeoecology and conservation. - Pak. J. Bot. 42: 231-258.

Daniela, C., Forino, L.M.C., Balestri, M. and Pagni, A.M. 2009. Leaf anatomical adaptations of Calystegia soldanella, Euphorbia paralias and Otanthus maritimus to the ecological conditions of coastal sand dune systems. - Caryologia 62: 142-151.

Evert, R.F. 2006. Esau's plant anatomy: meristems, cells, and tissues of the plant body: their structure, function, and development. - John Wiley \& Sons, New Jersey. $595 \mathrm{pp}$.

Fagaras, M., Jianu, L.D. 2016. Phytocoenoses whit Convolvulus persicus L. on the western coast of the Black sea. - JEPE 17: 1294-1304.

Fenu, G., Carboni, M., Acosta, A.T., and Bacchetta, G. 2012. Environmental factors influencing coastal vegetation pattern: new insights from the Mediterranean Basin. - Folia Geobot. 48: 493-508.

Irina, H., Carmen, V., Rodica, C. 2015. In vitro conservation of the critically endangered taxon Convolvulus persicus L. and regenerants evaluation. Biologia 31: 51-59.

Ghorbanli, m., Farzamisepehr, m., Jahani, 1. 2008. The study of eco-morphology and eco-physiology of two psammophyte plants on the coast of Caspian Sea. Plant Ecosys. 13: 25-41.

James, S.A., and Bell, D.T. 2000. Leaf orientation, light interception and stomatal conductance of Eucalyptus globulus ssp. globulus leaves. - Physiol. 20: 815-823.

Jones, L.A. 2011. Anatomical adaptations of four Crassula species to water availability. - Bioscience Horizons 4: 13-22.

Kelij, S. 2013. Anatomical and metabolic changes of lignin deposition at different developmental stages in halophyte Aeluropous littoralis Parl. - Ph.D. thesis, Kharazmi University.

Kelij, S., Mohamadjani, Z. and Naqinezhad, A. 2018. The effect of ecological factors on leaf and petiole anatomy of wild grapevine (Vitis vinifera subsp. sylvestris) in northern Iran. - Nova Biol. Reperta 4: 361-372. (In Persian)

Kuster, V.C., da Silva, L.C., Meira, R.M.S.A., and Azevedo, A.A. 2018. Structural adaptation and anatomical convergence in stems and roots of five plant species from a "Restinga" sand coastal plain. Flora 243: 77-87.

Leroux, O. 2012. Collenchyma: a versatile mechanical tissue with dynamic cell walls. - Ann. Bot. (Oxford). 110: 1083-1098.

Moura, J.C.M.S., Bonine, C.A.V., De Oliveira Fernandes Viana, J., Dornelas, M.C., and Mazzafera, P. 2010. Abiotic and biotic stresses and changes in the lignin content and composition in plants. - J. Integr. Pl. Biol. 52: 360-376.

Perrone, R., Salmeri, C., Brullo, S., Colombo, P., and De Castro, O. 2015. What do leaf anatomy and micromorphology tell us about the psammophilous

$$
\begin{aligned}
& \text { شاخص جمعيت بابلسر، ضخامت بيشتر يهنك آن در مقايسه با } \\
& \text { ساير جمعيتها است. }
\end{aligned}
$$

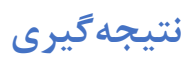

$$
\begin{aligned}
& \text { تجزيه و تحليل نتايج اين مطالعه، اطلاعاتى را در مورد }
\end{aligned}
$$

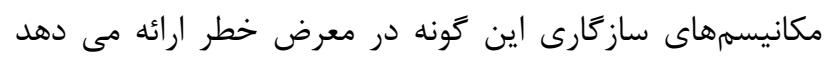

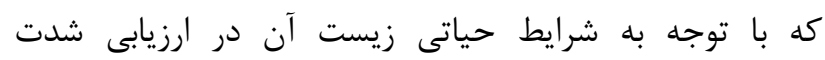

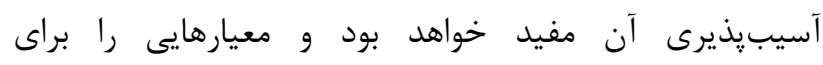

$$
\begin{aligned}
& \text { تصميمزيرىهاى آينده در اختيار ما مى گذارد. در حقيقت تنوع }
\end{aligned}
$$

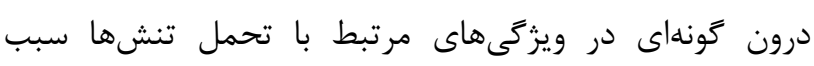

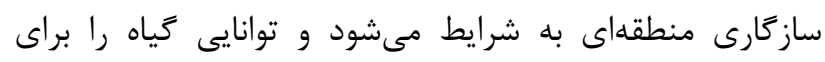

$$
\begin{aligned}
& \text { مقابله با تغييرات محيطى افزايش مى مدهد. } \\
& \text { از همكارى سه ايستغاه هواشناسى اميرآباد سارى، بابلسر و } \\
& \text { نوشهر و همجنين زحمات كارشناسان آزمايشعاه علوم گياهى } \\
& \text { دانشعاه مازندران، خانم زينب حسين زاده و خمانم } \\
& \text { سياسگزارى مى نماييم. }
\end{aligned}
$$


Pancratium maritimum L. (Amaryllidaceae) in response to sand dune conditions? - Flora 213: 20-31.

Safavi, S.R. 2016. Introducing a number of rare and endangered plants of the country. 3nd Conference on New Findings in Environment and Agricultural Ecosystems. University of Tehran, Tehran, Iran. pp: 77-95.

Sánchez-Aguayo, I., Rodríguez-Galán, J.M., García, R., Torreblanca, J., and Pardo, J.M. 2004. Salt stress enhances xylem development and expression of Sadenosyl-L-methionine synthase in lignifying tissues of tomato plants. - Planta 220: 278-285.

Strat, D. and Holobiuc, I.M. 2018. The occurrence and conservation status of Convolvulus persicus L. (Solanales: Convolvulaceae) on the western Black Sea coast-Romania. - Acta Zool. Bulg. 11: 125-132.

How to cite this article:

Asheqian, F., Kelij, S. and Jafari, N. 2020. The structural adaptations of Convolvulus persicus, an endangered plant in the northern coasts of Iran. - Nova Biol. Reperta 6: 495-504. (In Persian)

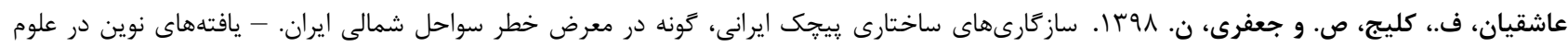

زيستى ؟ 